\title{
MENINGKATKAN HASIL BELAJAR PAK SISWA KELAS XI A2 DENGAN MENGGUNAKAN MODEL PEMBELAJARAN LEARNING TOGETHER
}

\author{
Hendrijeti Titaley \\ SMK Negeri 1 Ambon \\ Htitaley16@gmail.com
}

\begin{abstract}
Teachers who conduct Class Action Research are the right solution to improve the quality of learning in the classroom and reform in teaching more professional teachers to need to update learning. The reforms meant here are about conventional teaching methods becoming innovation.

Regarding the above problems, it requires special skills from teachers to use various innovative teaching approaches. To find out the effectiveness of these various learning models, the teacher must take an action called CAR in the classroom to improve the quality of teacher teaching.

After taking action in class, namely doing PTK in class to class XI A2 students at SMK Negeri 1 Ambon in improving student learning outcomes by using the Learning Together Learning Model seen in Cycle I which was carried out in class 9 students (34.62\%) obtained PAK learning outcomes scores are below the average, 8 students (30.77\%) are on average, and 9 others (34.62\%) are above average, while learning is done using the visual image method. In Cycle II, 9 people (34.62\%) obtained PAK learning outcomes below the average, 10 students $(38.46 \%)$ were on the average, and 7 others (26.92\%) were above average.
\end{abstract}

\section{Keywords: Learning outcomes PA, learning together learning model}

\section{PENGANTAR}

Menerut Boelke ( 1997 : 273 ) ia mengatakan bahwa hal belajar PAK secara umum dapat dibedakan atas tiga jenis hasil belajar yaitu : (1) hasil belajar cognitif yang mencakup bertambahnya pengetahuan dan perbuatan; (2) hasil belajar afektif yang mencakup perubahan sikap dan perasaan terhadap apa yang dipelajari; (3) hasil belajar psikomotor yang mencakup perubahan tingkah laku siswa sebagai pencerminan aplikasi siswa tentang bahan yang diajarkan dalam hidup sehari - hari. Selanjutnya Boelke yang dikutip Sumadikarya (2002 : 32) mengata-kan bahwa hasil yang dipelajari dalam PAK yakni pengetahuan, pemahaman, sikap nilai, ketrampilan, motif dan perubahan yang berkaitan dengan proses evaluasi. Sejalan dengan itu Goldman (1976 : 65) katakan bahwa hasil belajar PAK adalah penguasaan pengetahuan ketrampilan, prilaku yang memiliki inte- gritas diri maupun memanusiakan sesamanya dengan berbagai kehidupan yang sejahtera yang dikaruniakan Allah kepada manusia. Selanjudnya ia mengatakan bahwa kebutuhan nara didik haruslah menjadi titik awal demi tujuan PAK.

Menurut Kristianto ( 2006 : 134 ) katakan bahwa evaluasi bukanlah titik terakhir. Evaluasi yang berkelanjutan merupakan aspek pokok dari seluruh pelayanan pendidikan. Evaluasi melihat program, murid, proses, kemajuan dan produk. Evaluasi dilakukan untuk mengukur kemajuan dan menentukan apa yang telah dipenuhi atau diselesaikan. Proses evaluasi mungkin hasilnya berbeda dengan tujuan sebelummya. Sedangkan menurut Hamalik ( 1991 : 4 ) ia katakan bahwa apa pun bentuk strategi belajar akhirnya harus disertai dengan kegiatan penilaian yang dilakukan dalam bentuk penilaian awal, penilaian proses, dan penilaian hasil belajar 
Dari berbagai pendapat para ahli di atas mengenai hasil belajar PAK, maka dapatlah Penulis simpulkan bahwa belajar dapat merubah pemahaman dan pengetahuan siswa, belajar dapat membantu siswa dari tidak tahu menjadi tahu dan trampil. Tetapi hasil belajar seseorang bukan saja terbatas pada pengetahuan dan ketrampilan saaja, bahkan lebih dari pada itu yakni membentuk sikap dan prilaku yang baik.

\section{Tinjauan Literatur}

\section{Hakekat Model Pembelajaran koo-} peratif Learning Together.

Model Pembelajaran

Dalam kehidupan sehari-hari kata model tidaklah asing seperti model baju, model rumah tipe tertentu, model tata kota dsb. Arti khusus dari model menurut Neugebauer seperti yang dikutip Stachowiak (1980) adalah sebagai representasi yang sistimatis, singkat dan menyeluruh dari realitas dalam bentuk yang mudah dipahami.

Untuk menyusun sebuah model, mula-mula diawali dengan pengumpulan dan pengkajian pengetahuan teoritis yang relevan dengan tujuan dan bentuk model yang akan disusun. Kemudian berdasarkan hasil pengkajiaanya pengetahuan teoritis tersebut akan ditarik kesimpulan secara deduktif sebagai dasar untuk menyusun suatu model. Model di atas disebut model rasionil karena disusun berdasarkan teoritis. Terkait dengan proses pembentukan model tersebut, dalam penelitian ini dibatasi pada model pengajaran yang bersifat rasional yang disusun berdasarkan teori yang terkait dengan pembelajaran kooperatif dalam penelitian tindakan ini.

Menurur Sumiyatiningsi ( 2006 : 74 ) ia mengatakan bahwa model yang dipilih sebaiknya relevan dan mendukung tercapainya tujuan pengajaran. Dengan demikian, pertimbangan utama dalam pemilihan model adalah tujuan yang akan dicapai. Atujuan tersebut biasanya terjabar dalam kompetensi dasar, indikator, maupun materi pembelajaran. Jadi pemilihan model pembelajaran tidak dapat dipaksakan apabila tidak ada relevansi dengan pencapaian tujuan.

Ada beberapa ciri umum yang dimiliki oleh sebuah model adalah : (1) sistematis, yakni model yang memiliki langkah-langkah dengan urutan yang jelas, (2) singkat, yakni model diformulasikan secara sederhana sehingga memungkinkan untuk dikembangkan atau divariasikan sesuai dengan tujuan khusus penggunaannya, (3) sederhana, yakni model diciptakan untuk mudah dimengerti dan digunakan. Model pembelajaran menuurut Flechsig seperti yang dikutip Stachowiak (1980) didefinisikan sebagai rekonstruksi dan kontruksi yang konseptual - simbolis dari pembelajaran yang memenuhi persyaratan psikologi dan mengacu kepada tujuan tindakan yang dapat dipahami. Dijelaskan pula, bahwa model pengajaran harus menggambarkan pola interaksi yang jelas di dalamnya tercakup tujuan belajar, isi atau bahan ajar pelajaran, kegiatan belajarmengajar dan media yang digunakan, dan prasyaratan sosiokultural.

Dari berbagai pendapat yang diuraikan di atas, dapatlah disimpulkan bahwa model pengajaran adalah 
MENINGKATKAN HASIL BELAJAR PAK SISWA

KELAS XI A2 DENGAN MENGGUNAKAN MODEL PEMBELAJARAN LEARNING TOGETHER

merupakan sebuah pola interaksi atau kerangka kerja yang disusun secara sistematis, singkat, dan sederhana untuk menjadi pedoman dasar yang dapat diembangkan dan divariasikan sebagai prosedur instruksional daalam proses belajar - mengajar.

\section{a. Model Pembelajaran Kooperatif}

Menurut Ratumanan dalam Kauchak dan Eggen ( 2004 : 129 ) mengatakan bahwa belajar kooperatif merupakan suatu kumpulan strategi mengajar yang digunakan siswa untuk membantu satu dengan yang lain dalam mempelajari sesuatu. Selanjudnya Ratumanan dalam Slaving ( 2004 : 130 ) mengemukakan bahwa dalam pembelajaran kooperatif siswa bekerja sama dalam kelompok kecil saling membantu untuk mempelajari suatu materi. Sejalan dengan itu juga Ratumanan dalam Thomdson dan Smith (2004 : 130) bahwa dalam pembelajaran kooperatif, siswa bekerja sama dalam kelompok-kelompok kecil untuk mempelajari materi akademik dan ketrampilan antar pribadi. Anggota-anggota kelompok bertanggung-jawab atas ketuntasan tugastugas kelom-pok dan untuk mempelajari materi itu sendiri.

Untuk menjelaskan model pembelajaran kooperatif di atas menurut Ratumanan ( 2004 : 130 ) mengatakan bahwa ada beberapa karakteristik dari pembelajaran kooperatif, yakni sebagai berikut :

a. Kelas dibagi atas kelompokkelompok kecil. Anggota-anggota kelompok terdiri dari siswa dengan kemampuan yang bervariasi yakni tinggi, sedang dan rendah. Jika mungkin dalam pembentukan kelompok juga diperhatikan perbedaan suku, budaya, jenis kelamin, latar belakang sosial ekonomi, dan sebagainya.

b. Siswa belajar dalam kelompoknya secara kooperatif untuk menguasai materi akademis. Tugas anggaota kelompok adaalah saling membantu teman sekelompoknya untuk mencapai ketuntasan belajar.

c. Sistem penghargaan lebih berorientasi kepada kelompok dari pada individu.

Dari uraian-uraian di atas, dapat disimpulkan bahwa dalam pembelajaran kooperatif terdapat saling ketergantungan pasitif di antara siswa untuk mencapai tujuan pembelajaran. Setiap siswa mempunyai kesempatan yang sama untuk sukses. Aktivitas belajar berpusat pada siswa dalam bentuk diskusi, mengerjakan tugas bersama, saling membantu dan saling mendukung dalam memecahkan masalah. Melalui interaksi belajar yang efektif siswa lebih termativasi, percaya diri, mampu menggunakan strategi berfikir tingkat tinggi, serta mampu membangun hubungan interpersonal. Model pembelajaran kooperatif memung-kinkan hubungan semua siswa dapat menguasai materi pada tingkat penguasaan yang relatif sama atau sejajar.

\section{b. Model Pembelajaran Lerning Together \\ Belajar bersama (Learning Together) merupakan model belajar kooperatif yang dikembangkan oleh David Johnson dan}


Roger Johnson dan koleganya dari Universitas Minnesota. Model ini melibatkan siswa yang bekerja dalam kelompok-kelompok heterogen beranggotakan empat atau lima anggota. Kelompok-kelompok ini menengani tugas terten-tu yang telah dipersiapkan guru, Hasil kerja kelompok diserahkan untuk dinilai dan menerima pujian serta ganjaran sesuai dengan hasil kerja tersebut. Belajar bersama ini memberi tekanan pada kegiatan-kegiatan pembinaan kerjasama kelompok sebelum siswa mulai bekerja sama dan melakukan diskusi terjadwal di dalam kelompok. Menurut Ratumanan (2002 : 123) mengatakan bahwa pembe-lajaran kooperatif tipe Learning Together ini terdiri dari empat elemen yakni:

a. Interaksi face to face: Siswa bekerja dalam kelompok-kelompok kecil beranggotakan 4-5 orang.

b. Interpendensi positif: Siswa bekerja bersama untuk mencapai tujuan kelompok.

c. Akuntabilitas individual: Siswa harus menunjukkan bahwa secara individual mereka menguasai materi pelajaran.

d. Interpersonal dan ketrampilan kelompok kecil: Siswa seharusnya belajar secara efektif, menggunakan bekerja sama dan mendiskusikan bagaimana kelompok mereka bekerja untuk mencapai tujuan.

Menurut Kristianto ( 2006 : 84 ) ia katakan kelas dibagi dalam kelompok yang terdiri dari, misalnya, 3-6 orang atau sitidak-tidaknya dibbagi seadil dan serata mungkin. Mereka akan berdiskusi dengan topik khusus dan waktu yang terbatas.
Garis besarnya adalah (1) mempersiapkan topikkhusus, yang sama atau berbeda, untuk setiap kelompok; (2) mempersiapkan kertas kerja dan tempat yang cukup untuk membuat ringkasan; (3) memilih seorang pemimpin untuk setiap kelompok atau menjelaskan bagaimana suatu kelompok memilih pemimpin; (4) guru mengun-jungi setiap kelompok untuk mendorong dan membentu; akhirnya (5) mereka masuk dalam kelompok besar atau kelompok kecil.

Selanjudnya Kristianto katakan secara bersama-sama, setiap kelompok berdiskusi untuk mencari jalan keluar, sedangkan guru meringkas. Metode kelompok mendorong murid untuk berinteraksi dalam kelompok kecil, menuangkan ide-ide atau pengetahuan baru, menerapkan kebenaran Firman Tuhan dan membuat murid tertarik dan berpartisipasi. Laporan yang telah dibuat setiap kelompok dapat dipakai untuk masa yang akan datang.

Belajar bukan saja terbatas di dalam kelas tetapi akan bisa berlanjut terus sampai di luar kelas. Untuk itu, guru harus dapat memberikan motivasi dan kesan kepada siswa agar tetap belajar dan berada dalam kelompok belajar. Menurut Silberman ( 2009 : 166 )mengatakan bahwa kelompok belajar itu baik karena metode ini memberi siswa tanggungjawab untuk mempelajari materi pelajaran dan menjabarkan isinya dalam sebuah kelompok tanpa campurtangan guru. Tugas yang diberikan mesti jelas betul untuk memastikan bahwa sesi belajar yang dihasilkan akan efektif dan kelompok bisa mengatur diri mereka sendiri. Selanjutnya menurut Silberman ( 2009 : 281 ) katakan 
MENINGKATKAN HASIL BELAJAR PAK SISWA

KELAS XI A2 DENGAN MENGGUNAKAN MODEL PEMBELAJARAN LEARNING TOGETHER

bahwa tetaplah belajar strategi ini memungkinkan siswa menemukan cara-cara untuk terus mempelajari mata pelajaran yang Anda ajarkan. Prosedur : (1) Kemukakan harapan Anda agar siswa tidak berhenti belajar hanya karena pelajaran telah berakhir; (2) Kemukakan kepada siswa bahwa ada banyak cara bagi mereka untuk terus belajar secara mandiri; (3) Tunjukkan bahwa salah satu caranya aadalah dengan membuat daftar berisi gagasan mereka sendiri untuk "terus mempelajari."; (4) Buatlah sub-sub kelompok. Perintahkan setiap sub kelompok untuk mencetuskan gagasan. Contohnya Carilah artikel majalah, koran dsb, yang terkait dengan mata pelajaran. Cari pekerjaan atau tugas yang menggunakan ketrampilan yang telah kalian pelajari.

\section{METODE PENELITIAN}

Yang subjek penelitian (PTK) di sini adalah siswa kelas XI A2 SMK Negeri 1 Ambon yang menjadi focus penelitian tindakan. Perencanaan pengembabgan pembelajaran di sekolah dirinci sesuai dengan pengembangan dan inovasi pembelajaran yang dimulai dengan tahapantahapan. Tahapan yang dimaksud yang berkaitan dengan prosedur PTK yakni beberapa tahap antara lain : Perencanaan, pelaksanaan tindakan, observasi dan refleksi.

Penelitian tindakan dilakukan dalam tiga siklus. Tiap siklus terdiri dari tahapan-tahapan pengajaran dilakukan sesuai langkah-langkah. Setelah 1 siklus selesai maka akan dilakukan refleksi untuk mengetaahui hasil pembelajaran yang dilakukan dan hal-hal apa saja yang perlu diperbaiki untuk siklus berikutnya.

\section{a. Perencanaan Tindakan}

Perencanaan tindakan yang disusun dalam Siklus I ini terdiri dari perangkat pembe-lajaran yang siapkan, instrumen observasi yang di isi oleh teman sejawat dan alat evaluasi yang akan dipakai pada akhir Siklus I. Dalam perencanaan Peneliti melaksanakan melalui langkah- langkah di antaranya :

- Memberikan motivasi dan apresepsi

- Menjelaskan indikator dan tujuan pembelajaran.

- Siswa melakukan permainan kartu indeks.

- Siswa mencari pasangan kelompok sesuai petunjuk kartu indeks yang diperoleh.

- Siswa duduk berdasarkan kelompok sesuai dengan kategori indeks kartu.

- Guru menjelaskan garis - garis besar materi pelajaran.

- Siswa kerja kelompok.

- Guru dan siswa sama-sama memberikan kesimpulan akahir.

\section{b. Pelaksanaan Tindakan}

\section{Tahap I Penghayatan}

(Pertemuan I, 2 x 45 Menit) Peneliti menyampaikan standar kompetensi (SK), kompetensi dasar (KD), indika-tor dan tujuan pembelajaran yang harus dicapai oleh siswa.

Tindakan pertama yang dilakukan Peneliti adalah dengan cara permainan kartu indeks dimana Peneliti mengkocok 
kartu-kartu yang sudah di tulis dengan kode indeks yang terdiri dari kategori 1, kategori 2, kategori 3, dan kategori 4. Peneliti menyuruh setiap siswa mengambil 1 kartu indeks sampai selesai. Tindakan selanjudnya Peneliti menyuruh setiap siswa untuk mencari pasangan yang sesuai dengan kode indeks kartu. Selanjudnya mereka berkumpul dan membentuk 4 kelompok ajar sesuai dengan materi kategori 1, 2, 3, dan 4. Kemudian langkah berikut setiap ketua kelompok maju ke depan meja guru Peneliti untuk mengambil kartu indeks kategori materi diskusi kelompok 1, 2, 3, dan 4 yang langsung diberikan oleh Peneliti.

\section{Tahap II Penetapan}

Siswa mengerjakan materi diskusi kelompok dan guru peneliti sedang memantau apa yang sedang dikerjakan kelompok..

\section{Tahap III Tahap Penggunaan}

Pada tahap ini setiap kelompok mengerjakan tugas kelompok sesuai dengan kategori indeks kelompok 1, 2, 3, dan 4 sesuai dengan petunjuk. Langkah pertama yang harus dilakukan kelompok adalah melihat gambar-gambar yang ada hubungan dengan tema setiap kategori indeks. Setiap kelompok mengerjakan tugas sesuai dengan langkah-langkah petunjuk yang ada di dalam LKS.

\section{c. Observasi}

Berdasarkan tindakan, hasil observasi, dan hasil diskusi bersama kenyataanya masih terdapat kelemahan. Siswa belum dapat mengerjakan tugas kelompok dengan baik karena belum dapat menterjemahkan pesan yang ada di balik gambar-gambar dengan tepat. Dari beberapa catatan yang dicatat oleh Peneliti dan dari hasil diskusi bersama dengan kolaborator walaupun ada terdapat kelemahan subjek penelitian, tetapi pada prinsipnya ada sedikit perubahan hasil pembelajaran dengan menggunakan Cooperatif Learning Together.

Kelemahan lain yaitu ada beberapa anggota dari setiap kelompok yang masih dominan dalam memberikan pendapat, pada hal anggota kelompok lain punya kesempatan untuk memberikan pesan pesan yang ada di gambar pada tugas kelompok masing-masing. Kesimpulan yang adapa diambil bahwa Kemampuan siswa kelas XI A2 SMK Negeri 1 Ambon sangat berbeda, hal ini nampak terlihat pada hasil yang diperoleh belum mencapai target dan belum memuaskan walaupun ada perubahan tetapi itu dirasakan belum signifikan. Oleh karena itu, menurut Peneliti maka perlu adanya perbaikan-perbaikan pada strategi pembelajaran di Siklus II. Kesimpulan yang dapat diambil bahwa hasil pembelajaran PAK pada Siklus I belum memuaskan. Kesimpulan ini diambil berdasarkan hasil tes hasil belajar pada Siklus I ternyata tingkat pencapaian ketuntasan belajar siswa dalam pembelajaran PAK dengan menggunakan tipe cooperatif Learning Together dapat dikatakan baru mencapai $75 \%$.

\section{d. Evaluasi - Refleksi}

Berdasarkan hasil observasi, hasil diskusi dan refleksi bersama kolaborator maka selama proses tindakan berlansung di kelas ternyata kemampuan siswa kelas XI A2 SMK Negeri 1 Ambon dalam 
MENINGKATKAN HASIL BELAJAR PAK SISWA

KELAS XI A2 DENGAN MENGGUNAKAN MODEL PEMBELAJARAN LEARNING TOGETHER

meng-gunakan Model Pembelajaran Learning Together masih kurang, hal ini tampak pada hasil kerja kelompok yang belum maksimal, ini disebabkan belum kompak karena sebagian anggota dari setiap kelompok belum semua yang diberi kesempatan untuk mengeluarkan pendapat dan menanggapi pesan yang ada di gambar yang ada kaitan dengan materi kategori indeks 1, 2, 3, dan 4. Berdasarkan kesimpulan akhir di atas maka di pandang perlu khusus untuk Peneliti menerangkan dengan jalan atau tindakan apa yang diambil guna mengatasi atau mengurangi kelemahan yang terjadi? Dengan demikian pengajar perlu mengambil langkah untuk merobah strategi pembelajaran yang lebih efektif, kreaktif dan inovatif, dan dapat memotivasi siswa di dalam proses pembelajaran khusus belajar dengan menggunakan Model Pembelajaran Learning Together.

\section{Siklus II}

Penelitian Tindakan kelas (PTK) Siklus II pada hari Rabu, 8 Pebruari 2017.

\section{a. Perencanaan Tindakan}

Dalam perencanaan tindakan kelas pada Siklus II ini akan dilakukan dalam 3 tahap strategi pembelajaran yang akan dilakukan di kelas. Peneliti mempersiapkan kelemkapan mengajar meliputi: Menyiapkan perangkat pembelajaran, lembar data observasi yang di isi oleh teman sejawat dan alat instrumen evaluasi yang sama pada Siklus II. Untuk persiapan ke arah itu, Peneliti bersama dengan kolaborator mencoba untuk mempariasikan strategi pembelajaran agar dapat menarik perhatian siswa dalam proses tindakan yang akan berlangsung di kelas. Oleh sebab itu, Peneliti perlu saran dari kolaborator untuk meningkatkan kualitas pembelajaran, kalau itu pun dirasahkan penting. Apa pun bentuk masukan perlu dipertimbangkan oleh Peneliti itu penting maksudnya sebagai bahan pertimbangan dalam perbaikan rencana pelaksanaan strategi pelaksanaan (RPP) pada pelaksanaan tindakan Siklus II.

Dalam perencanaan penelitian, dapat digambarkan bahwa siswa secara keseluruhan dapat mengikuti mata pelajaran PAK dengan baik.

Di dalam perencanaan tindakan, Peneliti melakukan langkah - langkah sebagai berikut :

- Memberikan motivasi dan apresepsi.

- Menjelaskan indikator dan tujuan pembelajaran.

- Siswa melakukan permainan kartu indeks.

- Siswa mencari pasangan kelompok sesuai dengan kode kartu indeks yang diperoleh.

- Siswa duduk berdasarkan kelompok sesuai dengan petunjuk kategori indeks kartu.

- Guru menjelaskan garis - garis besar materi pelajaran.

- Siswa kerja kelompok dan belajar bersama untuk menyelesaikan tugas kelompok.

- Guru dan siswa sama - sama memberikan kesimpulan akhir. 


\section{b. Pelaksanaan Tindakan}

\section{Tahap I Penghayatan}

( Pertemuan I, 2 x 45 Menit ) Peneliti menyampaikan standar kompetensi ( SK ), kompetensi dasar ( KD ), indikator dan tujuan pembelajaran yang harus dicapai oleh siswa.

Tindakan pertama yang dilakukan Peneliti yaitu menerangkan materi ajar secara garis-garis besar sebelum siswa dibagi ke dalam kelompok.

\section{Tahap II Penetapan}

Pada tahap ini kelompok ada di dalam persiapan kelompok. Salah seorang peserta didik bertanya tentang mekanisme dalam diskusi di kelompok dan guru memberikan penjelasan tentang mekanisme kerja di kelompok.

\section{Tahap III Penggunaan}

Pada tahap ini setiap kelompok memfokuskan perhatian untuk menyelesaikan tugas di kelompok. Untuk membentu kelancaran kelompok di samping LKS juga ada gambar-gambar yang membantu sesuai dengan materi masing-masing kategori. Setiap anggota kelompok harus terlibat aktif dalam belajar bersama dan berdiskusi bersama untuk menjawab dan menyelesaikan materi yang ditentukan kepada setiap kelompok.

\section{c. Obsrvasi}

Berdasarkan tindakan yang dilakukan, hasil observasi, dan hasil diskusi bersama maka disimpulkan bahwa pembelajaran yang telah dicapai selama I Siklus (Siklus II) ternyata hasil yang diperoleh siswa sangat memuaskan dan dapat dikatakan berhasil. Berdasarkan hasil tes ternyata tingkat pencapaian siswa dalam pembelajaran PAK dengan tipe Cooperatif
Learning Together dapat dika-takan baik. Hasil yang diperoleh mencapai skor nilai $95 \%$.

\section{d. Evaluasi - Refleksi}

Berdasarkan hasil observasi, diskusi dan refleksi bersama kolaborator maka kesimpulan selama proses tindakan kelas berlangsung ternyata kemampuan hasil belajar PAK siswa kelas XI A2 SMK Negeri 1 Ambon sangat baik hasilnya karena dalam proses pembelajarannya menggunakan Learning Together. Dengan demikian siswa dapat belajar bersama dengan mudah, berdiskusi bersama, memecahkan persoalan secara bersama. Cara ini sangat mengairahkan semangat dan memotivasi siswa dalam belajar PAK.

Dilihat dari hasil Siklus II ini, maka berdasarkan hasil diskusi bersama dan berbagai pertimbangan, maka sudah menjadi kesepakatan bersama di antara Peneliti dan Kolaborator maka kesimpulan akhir yang diambil bersama, diputuskan bersama, sudah mencapai target di atas ketuntasan minimal belajar yang ditetapkan KKM 65.

\section{HASIL PENELITIAN DAN PEMBA- HASAN}

Penelitian ini merupakan penelitian tindakan kelas maka cara penelitian dilakukan melalui beberapa tahap antara lain : Perencanaan, pelaksanaan tindakan, observasi, evaluasi dan refleksi.

Penelitian tindakan kelas dilaksanakan dalam II Siklus dan tahapan-tahapannya sebagai berikut:

\section{Siklus I}

Penelitian tindakan kelas (PTK) Siklus I sesuai jadwal harian kelas XI A2 SMK 
MENINGKATKAN HASIL BELAJAR PAK SISWA

KELAS XI A2 DENGAN MENGGUNAKAN MODEL

PEMBELAJARAN LEARNING TOGETHER

Negeri 1 Ambon hari Rabu 1 Pebruari 2019

\section{a. Perencanaan Tindakan}

Dalam tahap ini Peneliti mempersiapkan perangkat pembelajaran yang meliputi (Skenaryo, materi ajar, alat pembelajaran, instrumen evaluasi), lembar data observasi yang di isi oleh teman sejawat.

\section{b. Pelaksanaan Tindakan}

Tahap I (Pertemuan 1). Peneliti menyampaikan standar kompetensi (SK), kompetensi dasar (KD), indikator dan tujuan pembelajaran yang harus dicapai oleh siswa. Peneliti menjelaskan langkahlangkah strategi pembelajaran PAK dengan menggunakan Model Pembelajaran Learning Together.

\section{c. Observasi}

Obsevasi mencakup proses tindakan dan hasil pembelajaran PAK yang telah dicapai selama I (satu) Siklus. Berdasarkan hasil tes ternyata masih terdapat kelemaha-kelemahan siswa karena ada beberapa siswa saja yang berperan aktif sedangkan sebaian siswa tidak diberi kesempatan. Belum tentu siswa yang tidak diberi kesempatan itu dia tidak tau. Pemimpin kelompok harus berperan aktif karena Model Pembelajaran Learning Together adalah belajar bersama. Oleh karena itu Peneliti memakai sebuah cara yaitu permainan dengan menggunakan kartu indeks. Dari hasil observasi ternyata terjadi perubahan walaupun dalam skala sedikit pada hasil belajar PAK siswa kelas XI A2 SMK Negeri 1 Ambon dengan menggunakan Model
Pembelajaran Learning Together baru mencapai $75 \%$.

\section{d. Evaluasi - Refleksi}

Berdasarkan hasil evaluasi dan refleksi yang dilakukan oleh peneliti bersamasama kilaborator, maka selama proses tindakan kelas berlangsung, ternyata tingkat pencapaian hasil belajar PAK ternyata masih ada sebahagian siswa yang belum tuntas dan berhasil belajar PAK dengan menggunakan model pembelajaran Learning Togerher maka tingkat pencapaian hasil belajar PAK dapat terlihat pada tabel I di bawah ini :

\section{Tabel 1 Siklus I}

Distribusi Frekwensi Skor Hasil Belajar PAK dengan menggunakan model pembelajaran Learning Together.

\begin{tabular}{|c|cc|c|}
\hline No & Skor & Frekwensi Absolut & $\begin{array}{c}\text { Frekwensi Relatif } \\
(\%)\end{array}$ \\
\hline 1 & $50-55$ & 4 & $15.38 \%$ \\
2 & $56-60$ & 5 & $19.23 \%$ \\
3 & $61-65$ & 8 & $30.77 \%$ \\
4 & $66-70$ & 5 & $19.23 \%$ \\
5 & $71-75$ & 4 & $15.38 \%$ \\
\hline & Jumlah & $\mathbf{2 6}$ & $\mathbf{1 0 0} \%$ \\
\hline
\end{tabular}

Berdasarkan tabel 1 diperoleh data bahwa untuk siklus I, 9 orang siswa $(34,62 \%)$ memperoleh skor hasil belajar PAK di bawah rata-rata, 8 orang siswa $(30,77 \%)$ berada pada rata-rata, dan 9 orang lainnya $(34,62 \%)$ di atas rata-rata.

Histogram dari tabel 1 dapat di gambarkan sebagai berikut :

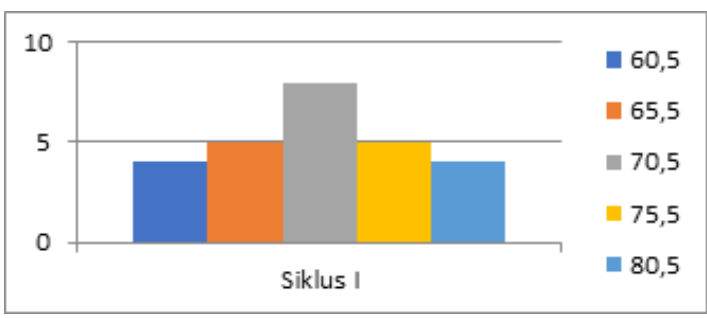


Pada tabel 1 di atas terlihat pada Siklus I proses pembelajaran PAK menunjukkan bahwa ada perubahan sedikit dan berpengaruh pada hasil belajar PAK siswa kelas XI A2 SMK Negeri 1 Ambon dengan menggunakan Model Pembelajaran Learning Together. Bagi siswa yang belum mencapai tingkat pencapaian ketuntasan hasil belajar PAK (KKM) tetap mereka diberikan waktu untuk remedial khusus.

\section{Siklus II}

\section{a. Perencanaan Tindakan}

Siklus II ini disusun berdasarkan data hasil evaluasi dan refleksi dari Siklus I yang disebut replaining dan sesuai perencanaan yang sudah diprogramkan. Perencanaan ulang khususnya pada pelaksanaan tindakan dalam Siklus II mulai dengan mempersiapkan perangkat pembelajaran meliputi : Skenaryo, materi ajar, alat pembelajaran, instrumen evaluasi yang berkaitan dengan tema pembahasan yang diberikan.

Siklus II dilaksanakan pada hari Rabu 8 Pebruari 2019

\section{b. Pelaksanaan Tindakan}

Pada tahap ini Peneliti memberikan motivasi kepada siswa agar mereka kompak dan sepakat bersama untuk menyelesaikan tugas-tugas yang dikerjakan bersama di kelompok.Siswa harus memecahkan masalah secara berurut-urutan dan itu dilakukan bersama. LKS dan gambar media sebagai alat bantu untuk memicu daya pikir siswa agar mereka dapat mengemukakan pendapat, mempertimbangkan dan memutuskan secara bersama-sama. Belajar bersama itu mempunyai kekuatan dan semangat yang tinggi, apalagi didukung dengan media.

\section{c. Observasi}

Berdasarkan catatan observasi dan hasil penelitiann juga dari hasil diskusi yang dilakuakn Peneliti bersama kolaborator maka terlihat ada perubahan yang signifikan. Berdasarkan hasil tes ternyata diperoleh tingkat pencapaian belajar siswa daalam pembelajaran PAK dengan Model Pembelajaran Learning Together dikategorikan baik dan berhasil. Dari hasil data tes yang diperoleh maka skor angka yang didapat sudah mencapai 95 $\%$.

\section{d. Evaluasi - Refleksi}

Peningkatan hasil belajar PAK yang diperoleh siswa kelas XI A2 SMK Negeri 1 Ambon dengan menggunakan model pembelajaran Learning Together ternyata dari hasil evaluasi punya hasil cukup baik dan memuaskan. Dari hasil yang diperoleh hanya ada 1 orang siswa saja yang belum tuntas karen nilainya masih kurang 1 untuk mencapai KKM 73. Untuk yang belum tuntas tetap menjadi prioritas oleh karena itu, ia harus diberikan remedial khusus. Untuk itu kita sampai pada kesimpulan akhir, berdasarkan hasil tes pada akhir tindakan Siklus II ini, dapat dilihat hasil peningkatan belajar PAK siswa kelas XI A2 SMK Negeri 1 Ambon dengan menggunakan Model Pembelajaran Learning Together. Untuk itu, maka tingkat pencapaian hasil belajar PAK daapat terlihat dengan jelas pada tabel 2 di bawah ini. 


\section{Tabel Siklus II}

Distribusi Frekwensi Skor Hasil Belajar PAK dengan menggunakan Model Pembelajaran Learning Together.

Keterangan Tabel 2. Siklus II : Distribusi Frekwensi Skor Hasil Belajar PAK dengan menggunakan Model Pembelajaran Learning Together

\begin{tabular}{|ccc|c|}
\hline No & Skor & $\begin{array}{c}\text { Frekwensi } \\
\text { Absolut }\end{array}$ & $\begin{array}{c}\text { Frekwensi } \\
\text { Relatif } \\
\text { ( \% ) }\end{array}$ \\
\hline 1 & $60-65$ & 4 & $15,38 \%$ \\
2 & $66-70$ & 5 & $19.23 \%$ \\
3 & $71-75$ & 10 & $38.46 \%$ \\
4 & $76-80$ & 4 & $15.38 \%$ \\
5 & $81-85$ & 3 & $11.53 \%$ \\
\hline & Jumlah & $\mathbf{2 6}$ & $\mathbf{1 0 0} \%$ \\
\hline
\end{tabular}

Berdasarkan tabel 2 diperoleh data bahwa untuk Siklus II, 9 orang $(34,62 \%)$ memperolehan skor hasil belajar PAK di bawah rata-rata, 10 orang siswa $(38,46 \%)$ berada pada rata-rata, dan 7 orang lainnya ( $26,92 \%$ ) di atas rata-rata.

Histogram dari tabel 2 dapat di gambarkan sebagai berikut :

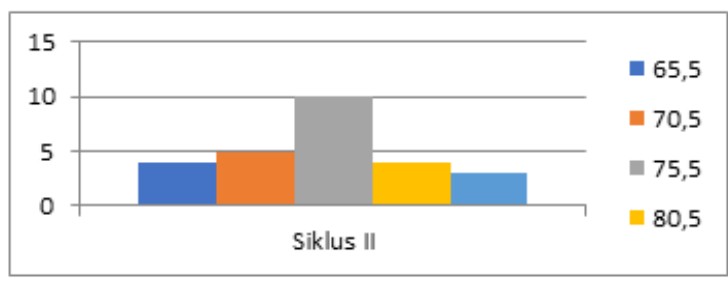

Pada tabel 2 di atas terlihat pada Siklus II proses pembelajaran yang dilakukan di pantai dapat meningkatkan hasil belajar PAK siswa kelas XI A2 SMK Negeri 1 Ambon dengan menggunakan Model Pembelajaran Learning Together. Walau pun ada sebagian kecil darisiswa yang hasilnya belum mencapai standar kompetensi mereka ini harus mendapat perhatian khusus dan perlu dipacu sehingga mencapai hasil yang terbaik.

\section{KESIMPULAN}

Dari hasil pembahasan di atas dapat disimpulkan bahwa ada terdapat perbedaan hasil belajar PAK dengan menggunakan Model Pembelajaran Lerning Together dari Siklus I dan Siklus II. Hal ini dapat dibuktikan bahwa pembelajaran dengan menggunakan metode gambar visual pada Siklus I yang dilakukan di dalam kelas adalah 9 orang siswa $(34,62 \%)$ memperoleh skor hasil belajar dengan menggunakan model pembelajaran Learning Together di bawah rata-rata, 8 orang siswa $(30,77 \%)$ berada pada rata-rata, dan 9 orang lainnya $(34,62 \%)$ di atas rata-rata. Sedangkan pembelajaran yang dilakukan dengan menggunakan metode gambar visual pada Siklus II yang adalah 9 orang siswa $(34,62 \%)$ memperoleh skor hasil belajar dengan menggunakan metode gambar visual di bawah rata-rata, 10 orang siswa $(38,46 \%)$ berada pada rata-rata, dan 7 orang lainnya $(26,92 \%)$ di atas rata-rata.

Dengan menggunakan model pembelajaran Learning Together siswa akan lebih termotivasi dan terkonsentrasi terhadap tema yang diberikan di dalam kelompok-kelompok kecil, dan memberikan peluang untuksiswa lebih berani dalam mengungkapkan ide-ide ataupun gagasan yang ada kaitan dengan tugas pembelajaran di kelompok yang harus diselesaikan bersama. 
Mengajar dengan menggunakan model pembelajaran Learning Together secara baik tentunya memberikan kontribusi positif bagi siswa dalam meningkatkan kemampuan kritis dari siswa dan dapat mengungkapkan makna yang ada dibalik gambar maupun teks Alkitab.

\section{Ucapan Terima Kasih}

Pada kesempatan ini, kami mengucapkan terima kasih kepada SMK Negeri 1 Ambon yang telah bersedia menjadi objek penelitian bagi penulis. Terima kasih juga kepada Redaktur yang telah memberikan masukan yang berharga sehingga tulisan ini dapat disajikan di Jurnal Institutio, Terima kasih yang sama juga kami ucapkan kepada pengurus Jurnal Institutio yang telah memberi ruang diskusi

Semua bantuan dalam bentuk apapun yang diberikan kepada penulis, tidak dapat penulis balas satu persatusatu, hanya doa semoga kita semua dapat senantiasa dalam lindungan Tuhan.

\section{Pustaka Acuan}

Arikunto, S. 2006. Penelitian Tindakan Kelas.Jakarta : Penerbit Bina Aksara.

Boelke, Robert. R. 1997. Sejarah Perkembangan Pikiran dan Praaktek Pendidikan Agama Kristen. Jakarta : Penerbit Bpk Gunung Mulia.

Cully, Iris. V. 1976. Dinamika Pendidikan Kristen. Jakarta : Penerbit Bpk Gunung Mulia.

Goldman, N.J. 1976. The Theory Of Christian Education Practise. Alabama : Religious Education Press.
Hamalik, Oemar. 1991. Strategi Belajar Mengajar Berdasarkan CBSA. Bandung : Penerbit Sinar Baru.

Kristianto, P. L. 2006. Prinsip dan Praktik Pendidikan Agama Kristen. Yogyakarta : Percetakan Andi Offset.

Madya, Suwarsih. 2006. Praktek Penelitian Tindakan Kelas. Bandung : Penerbit Alfabeta.

Ratumanan, G. 2004. Belajar dan Pembelajaran. Penerbit : Unesa University Press.

Stachowiak, Herbert. 1980. Modile und Modelldenken im Untericht. Bad Heilbrunn : Verlag Julius Klinkhartt.

Sumiyatiningsih, Dien. 2006. Mengajar dengan Kretif dan Menarik. Yogyakarta : Percetakan Andi Offset.

Siberman, M. L. 2009. Active Learning 101 cara Belajar Siswa Aktif. Bandung : Penerbit Nusamedia.

Shara, Shlomo. 2009. Cooperative Learning. Yogyakarta : Penerbit Imperium.

Suyatno, 2009. Menjelajah Pembelajaran Inivatif. Sidoharjo : Masmedia Buana Pustaka.

Tim Penyusun Buku Redakasi BPK Gunung Mulia. 2002. Memperlengkapi Bagi Pelayan dan Pertumbuhan. Jakarta : Penerbit Bpk Gunung Mulia.

Wardani, IGAK. 2007. Penelitian Tindakan Kelas. Jakarta : Penerbit Universitas Terbuka.

Wenno, I. H. 2010. Desain Penelitian Pendidikan \& Teknik Analisa Data. Yogyakarta : Penerbit Grafika Indah. 